\title{
Hubungan antara total asupan energi dan komponen makrontrien dengan penambahan berat badan ibu hamil di Kecamatan Pedurungan Kota Semarang
}

\author{
Yuli Astuti $^{1 *}$, Yudi Mulyana Hidayat ${ }^{2}$, Enny Rohmawati ${ }^{3}$
}

\begin{abstract}
Background: Gestational weight gain $(G W G)$ is physiological change in pregnancy. Inadequate gestational weight gain $(I G W G)$ and excessive gestational weight gain $(E G W G)$ can pose a risk of complication such as gestational hypertention, low birth weight, giant baby, and premature birth. Food intake (energy and macronutrient) play important role in providing pregnancy needs such as fetal and placental growth, and also play role in fat accumulation in some part of mother's body.

Objectives: This study aims to analyze the relationship between energy intake and macronutrient and gestational weight gain of pregnant woman and to know the consumption of food groups.

Methods: This study was quantitative study using cohort prospective approach. 73 healthy pregnant women with normal body fat mass who met inclusion and exclusion criteria was weighed twice in a period of 8 weeks. 24 hours food recall in 2 unsecutive days was done between those times. The instruments used for this study were weight scale, stadiometer, and questionnaire. Nutritional analysis used Nutrisurvey and statistic analysis used Chi Square test.

Result: There was a relationship between total energy intake and gestational weight gain $(p=0.031)$ and there was no relationship between macronutrient component intake (carbohydrate, fat, and protein) and gestational weight gain $(p=0.175$, $p=0.97$, and $p=0.089$ respectively). Respondent characteristic that has corelation with GWG is number of pregnancy. Most pregnant woman experienced EGWG (56.2\%) and their food consumption not fulfilled the balance nutrient recommendation guidelines especially less in vegetables and fruits consumption.
\end{abstract}

Conclusion:There is a significant corelation between energy intake and GWG.

Keywords : gestational weight gain; energy; macronutient

\begin{abstract}
ABSTRAK
Latar Belakang: Penambahan berat badan hamil/ gestational weight gain $(G W G)$ merupakan hal fisiologis. Namun, apabila GWG kurang atau inadequate gestational weight gain $(I G W G)$ dan berlebihan atau excessive gestational weight gain (EGWG) dapat berisiko menimbulkan komplikasi seperti hipertensi dalam kehamilan, berat badan lahir bayi rendah (BBLR), bayi besar, dan kelahiran prematur. Asupan makanan (energi dan makronutrien) berperan penting dalam menyediakan kebutuhan kehamilan seperti pertumbuhan janin, plasenta, serta berperan dalam penumpukan lemak di beberapa bagian tubuh ibu.

Tujuan: Penelitian ini bertujuan menganalisis hubungan asupan energi dan makronutrien terhadap penambahan berat badan ibu hamil dan mengetahui konsumsi bahan pangannya.

Metode: Penelitian ini merupakan penelitian kuantitatif dengan pendekatan kohort prospektif. Sampel sejumlah 73 responden ibu hamil sehat dengan indeks masa tubuh normal yang sesuai dengan kriteria inklusi dan eksklusi. Penimbangan berat badan dilakukan 2 kali dalam kurun waktu 8 minggu dan 2 kali food recall diantara waktu tersebut. Alat ukur yang digunakan berupa timbangan berat badan dan kuesioner. Analisis nutrisi menggunakan Nutrisurvey dan uji statistik menggunakan uji Chi Square.

Hasil: Terdapat hubungan antara total asupan energi dengan penambahan berat badan ibu hamil $(p=0,031)$ dan tidak terdapat hubungan antara komponen makronutrien (karbohidrat, lemak, dan protein) dengan penambahan berat badan ibu hamil ( $p=0,175, p=0,097$, dan $p=0,089)$. Krateristik responden yang berhubungan dengan $G W G$ yaitu jumlah kehamilan $(p=0,021)$. Sebagian besar ibu hamil mengalami penambahan berat badan berlebihan (56,2\%). Konsumsi bahan pangan ibu hamil belum memenuhi anjuran pedoman gizi seimbang dengan masih kurangnya porsi sayuran dan buah-buahan.

Simpulan: Ada hubungan yang signifikan antara total asupan energi dan GWG.
\end{abstract}

Kata Kunci : berat badan hamil; energi; makronutrien

\footnotetext{
${ }^{1}$ Prodi Kebidanan, Fakultas Kedokteran, Universitas Islam Sultan Agung. Jl. Kaligawe Raya Km 4, Genuk, Semarang, Jawa Tengah, Indonesia

${ }^{2}$ Departemen Obstetri dan Ginekologi, Fakultas Kedokteran, Universitas Padjadjaran - Rumah Sakit Umum Pusat Hasan Sadikin.

J1. Prof Eyckman No.38, Pasteur, Kec. Sukajadi, Kota Bandung, Jawa Barat 40161, Indonesia

${ }^{3}$ Departemen Farmakologi, Fakultas Kedokteran, Universitas Padjadjaran. Jl. Prof Eyckman No.38, Pasteur, Kec. Sukajadi, Kota Bandung, Jawa Barat 40161, Indonesia

${ }^{*}$ Korespondensi : e-mail: yuli.astuti@unissula.ac.id
} 


\section{PENDAHULUAN}

Penambahan berat badan merupakan hal yang fisiologis terjadi selama kehamilan. Komponen penambahan berat badan terdiri dari pertumbuhan hasil konsepsi seperti janin, cairan amnion, dan plasenta. Penambahan berat badan ini juga dipengaruhi adanya perubahan hormon estrogen, progesteron, dan plasenta yang mengakibatkan terjadinya resistesi insulin dan penumpukan jaringan lemak tubuh. ${ }^{1}$ Ibu hamil disarankan mencapai penambahan berat badan yang optimal sesuai rekomendasi Institute of Medicine untuk menghindari berbagai komplikasi pada ibu dan bayi. ${ }^{2}$ Penambahan berat badan yang tidak adekuat atau inadequate gestational weight gain (IGWG) berhubungan dengan peningkatan risiko terjadinya bayi kecil masa kehamilan (KMK), bayi berat lahir rendah (BBLR), intra uterine growth retardation (IUGR), dan kelahiran prematur. ${ }^{2-6}$ Penambahan berat badan berlebihan atau excessive gestational weight gain (EGWG) berhubungan dengan peningkatan risiko bagi ibu maupun bayi. Risiko yang dapat terjadi pada ibu diantaranya hipertensi dalam kehamilan atau pre eklamsia, diabetes gestasional, dan persalinan dengan sectio caesarea (SC). ${ }^{7-10}$ Pada bayi, EGWG dapat berdampak pada terjadinya bayi dengan besar masa kehamilan (BMK), kelahiran prematur, dan makrosomia. $^{2,11,12}$

Di Indonesia, berbagai komplikasi yang berhubungan dengan penambahan berat badan hamil di atas masih banyak terjadi. Indonesia menjadi salah satu dari 10 besar negara di dunia dengan kejadian bayi dengan ukuran lebih kecil dari masa kehamilan (KMK) yang tinggi yaitu terjadi pada $23,8 \%$ kelahiran. ${ }^{13}$ Selain itu $10,2 \%$ bayi lahir mengalami BBLR, sedangkan kasus IUGR terjadi pada $8 \%$ kelahiran bayi. ${ }^{14,15}$ Saat ini tren GWG di negara-negara maju cenderung terjadi peningkatan pada kejadian EGWG. ${ }^{16}$ Sebaliknya, IGWG dan kekurangan nutrisi ibu hamil di negara tertinggal masih menjadi fokus. Di Indonesia sendiri data representatif mengenai penambahan berat badan ibu hamil masih terbatas. Namun, beberapa penelitian menunjukkan masih banyaknya ibu hamil yang mengalami penambahan berat badan tidak ideal. ${ }^{5,17}$

Salah satu faktor penting yang memengaruhi GWG yang dapat dimodifikasi yaitu faktor gaya hidup. Faktor gaya hidup tersebut meliputi pola makan, aktifitas fisik, konsumsi alkohol, dan merokok. ${ }^{2,18}$ Pola makan yang memengaruhi GWG yang utama dinilai dari total asupan energi yang didapat dari makronutrien (karbohidrat, protein, dan lemak) yang dikonsumsi ibu hamil. Kecukupan makronutrien dalam kehamilan merupakan hal yang esensial sebagai penunjang pertumbuhan dan perkembangan janin juga mencukupi kebutuhan kalori ibu. ${ }^{2}$ Menurut Tielemant et al, total asupan energi berhubungan dengan penambahan berat badan ibu hamil, namun efek dari masing-masing makronutrien masih inkonsisten. ${ }^{19}$

Total asupan energi dipengaruhi oleh berbagai jenis makanan yang dikonsumsi seperti makanan pokok, ikan, daging merah, daging unggas, kacangkacang, dan sebagainya. Beberapa penelitian terkini mengidentifikasi jenis kelompok makanan tertentu berhubungan dengan GWG seperti konsumsi ikan, susu, minuman berkalori, roti, dan camilan. ${ }^{20}$

Meskipun diketahui asupan energi sangat penting dalam kehamilan, namun menurut data Biro Pusat Statistik di Kota Semarang angka kejadian kekurangan energi kronis terus mengalami peningkatan dari tahun 2014 hingga 2016 yaitu dari 37.365 orang, 42.907 orang, dan 57.444 orang berturut-turut. Kecamatan Pedurungan sebagai kecamatan dengan jumlah sasaran ibu hamil tertinggi di Kota Semarang. Menurut penelitian Fitri pada ibu hamil trimester 1 dan 2 di Kota Malang didapatkan asupan energi, protein, dan lemak berhubungan dengan GWG. ${ }^{21}$ Penelitian Yang di China menunjukkan asupan energi berkorelasi positif dengan GWG, sementara persentase asupan karbohidrat dan protein terhadap asupan energi berkorelasi dengan GWG khususnya pada trimester 2 dan $3 .^{22}$

Penelitian ini bertujuan menganalisis hubungan total asupan energi dan komponen makronutrien dengan penambahan berat badan ibu hamil serta komsumsi jenis bahan makanan ibu hamil di Kecamatan Pedurungan Kota Semarang.

\section{BAHAN DAN METODE}

Penelitian ini merupakan penelitian kuantitatif dengan pendekatan kohort prospektif. Penelitian dilakukan pada bulan September 2018 - Pebruari 2019 di wilayah kerja Puskesmas Tlogosari Kulon dan Tlogosari Wetan Kecamatan Pedurungan, Kota Semarang. Populasi dalam penelitian ini adalah seluruh ibu hamil di Kecamatan Pedurungan Kota Semarang. Sampel dalam penelitian ini berjumlah 73 responden ibu hamil trimester 2 dan 3 usia kehamilan 16-28 minggu dengan kehamilan tunggal, usia 20-35 tahun, dan memiliki indeks masa (IMT) tubuh normal (18,5-25 $\mathrm{kg} / \mathrm{m}^{2}$ ) saat sebelum hamil yang dilihat dari data di buku Kesehatan Ibu dan Anak (KIA). Kriteria eksklusi dalam penelitian ini adalah responden diketahui memiliki komplikasi kehamilan pre eklamsia, hiperemesis gravidarum, diabetes gestasional, kehamilan ganda, menderita penyakit kronis, mengonsumsi alkohol dan obat terlarang, serta responden yang lupa hari pertama haid terakhir (HPHT)-nya.

Variabel dalam penelitian ini terdiri dari variabel bebas, terikat, dan karakteristik responden yang memungkinkan sebagai perancu. Variabel bebas dalam penelitian ini terdiri dari total asupan energi, 
karbohidrat, lemak, dan protein. Variabel terikat dalam penelitian ini merupakan penambahan berat badan. Variabel karakteristik terdiri dari usia, jumlah kehamilan, pekerjaan, tingkat pendidikan, pendapatan keluarga dan tingkat aktifitas fisik.

Identifikasi subjek penelitian dilakukan melalui data sasaran ibu hamil di Puskesmas yang memiliki data lengkap dan bisa dihubungi melalui telepon. Responden yang sesuai kriteria dihubungi dan dilakukan kunjungan rumah apabila bersedia. Setelah diberikan informed consent, dilakukan penimbangan dan pengukuran tinggi badan. Timbangan yang digunakan merupakan timbangan digital dengan ketelitian $0,1 \mathrm{~kg}$ yang telah dikalibrasi. Pada saat penimbangan responden hanya menggunakan pakaian ringan. Pengukuran tinggi badan dengan posisi kepala Frankfort horizontal. Pada pertemuan pertama ini juga dilakukan pengisian kuesioner identitas diri. Selanjutnya dilakukan 2 kali food recall pada hari yang tidak berurutan yang terdiri dari hari kerja dan hari libur. Wawancara food recall dilakukan oleh nutrisionis dengan food model sebagai alat bantu dan timbangan makanan bila dimungkinkan dilakukan penimbangan makanan. 8 minggu setelah kunjungan rumah pertama dilakukan penimbangan kedua dan pengisian Global Physical Acivity Questionnaire (GPAQ) untuk menilai aktifitas fisik responden dalam 8 minggu sebelumnya.

Data asupan makanan kemudian dianalisis menggunakan program Nutrisurvey untuk mendapatkan nilai total asupan energi dan makronutriennya sesuai dengan Tabel Komposisi Pangan Indonesia tahun 2018. Konsumsi jenis bahan pangan dihitung secara manual dan dikonversi menjadi satuan porsi dan dikelompokkan menjadi 9 kategori yaitu: makanan pokok, daging merah, daging unggas, ikan, kacangkacangan, telur, susu, sayur, dan buah. Satuan porsi digunakan berdasarkan tabel porsi makanan Pedoman Umum Gizi Seimbang. Selanjutnya dikategorikan asupan $\geq$ rerata $=$ tinggi dan $<$ rerata $=$ rendah. Untuk kategori kecukupan energi digunakan pengkategorian 1) sangat kurang $(<70 \%$ AKG), 2) kurang $(70-<100$ $\%$ AKG), 2) sesuai (100-<120\%AKG), dan 4) lebih $(>120 \% \mathrm{AKG}){ }^{23}$ Untuk kategori kecukupan protein dikategorikan menjadi 1) sangat kurang ( $<80 \%$ AKP), 2) kurang (80-100 \% AKP), 3) sesuai (100-<120\%AKP, dan 4) lebih ( $\geq 120 \% \mathrm{AKP}) .{ }^{23}$ Untuk pengkategorian lemak dibagi menjadi dua yaitu $\leq 100 \% \mathrm{AKG}$ dan > $100 \%$ AKG. Sedangkan karbohidrat dikategorikan menjadi 1) kurang ( $<80 \%$ AKG), 2) sesuai (80-110 $\%$ AKG), dan 3) lebih (>110 \%AKG). Angka kecukupan energi, protein, karbohidrat, dan lemak yang digunakan dalam penelitian ini menyesuaikan angka kecukupan energi sesuai Permenkes no 75 tahun 2013 tentang Angka Kecukupan Gizi Indonesia. ${ }^{24}$ Data penambahan berat badan dibagi menjadi 3 kategori sesuai dengan kriteria Institute of Medicine. Pembagian kategori tersebut antara lain: kurang: $<0,36 \mathrm{~kg} / \mathrm{minggu}$, normal: 0,36-0,45 kg/minggu, lebih: $>0,45 \mathrm{~kg} /$ minggu).

Seluruh data selanjutnya dilakukan coding, tabulating, dan cleaning dengan program komputer. Uji normalitas data menggunakan uji Shapiro-wilk. Data asupan energi dan komponen makronutrien yang berdistribusi normal dibagi menjadi dua kelompok (tinggi dan rendah) dengan cut of point rerata untuk data berdistribusi normal dan median untuk data yang tidak berdistribusi normal. Selanjutnya dilakukan uji Chi Square untuk menganalisis hubungan antara asupan energi dan makronutrien dengan GWG. Penelitian ini telah mendapat persetujuan etik/ethical clearance dari Komisi Etik Penelitian Kesehatan Universitas Padjadjaran dengan nomor 938/UN6.KEP/EC/2018.

\section{HASIL}

Tabel 1. Karakteristik Responden Berdasarkan Usia, Jumlah Kehamilan, Tingkat Aktifitas Fisik, Status Pekerjaan, Status Merokok Pendidikan, dan Pendapatan Keluarga

\begin{tabular}{|c|c|c|c|}
\hline No & Karakteristik & $\mathbf{n}$ & $\%$ \\
\hline \multirow[t]{4}{*}{1.} & Usia responden & & \\
\hline & $21-25$ & 22 & 30,14 \\
\hline & $26-30$ & 36 & 49,31 \\
\hline & $31-35$ & 15 & 20,54 \\
\hline \multirow[t]{3}{*}{2.} & Jumlah kehamilan & & \\
\hline & Primigravida & 38 & 52,05 \\
\hline & Multigravida & 35 & 47,94 \\
\hline \multirow[t]{3}{*}{3.} & Pekerjaan & & \\
\hline & Tidak bekerja & 38 & 52,05 \\
\hline & Bekerja & 35 & 47,94 \\
\hline \multirow[t]{3}{*}{4.} & Status merokok & & \\
\hline & Merokok & 0 & 0,00 \\
\hline & Tidak merokok & 73 & 100,00 \\
\hline \multirow[t]{4}{*}{5.} & Pendidikan & & \\
\hline & Dasar & 8 & 10,96 \\
\hline & Menengah & 33 & 45,20 \\
\hline & $\mathrm{Ak} / \mathrm{PT}$ & 32 & 43,83 \\
\hline \multirow[t]{3}{*}{6.} & Pendapatan keluarga & & \\
\hline & $<$ UMR & 19 & 26,03 \\
\hline & $>=\mathrm{UMR}$ & 54 & 73,97 \\
\hline \multirow[t]{3}{*}{7.} & Tingkat aktivitas fisik & & \\
\hline & Rendah & 52 & 71,23 \\
\hline & Sedang & 21 & 28,76 \\
\hline
\end{tabular}

Berdasarkan tabel 1, sebagian besar usia responden adalah 26-30 tahun (49,31\%). Dalam penelitian ini sebagian besar $(52,05 \%)$ responden adalah ibu primagrivida atau baru mengalami kehamilan pertama. Semua responden tidak merokok dan sebagian beaar aktivitas fisiknya rendah $(71,23 \%)$. Pendapatan keluarga sebagian besar di atas UMR $(73,97 \%)$ walaupun sebagian responden tidak bekerja $(52,05 \%)$. 
Konsumsi jenis bahan pangan ibu hamil di Kecamatan Pedurungan ditampilkan dalam tabel 2. Berdasarkan angka kecukupan gizinya, kecukupan energi dan makronutrien responden disajikan dalam tabel 3. Sebagian besar kecukupan energi responden masuk dalam kategori kurang. Begitu pula pada kecukupan lemak, sebagian besar responden berada dalam kategori kurang $(63,01 \%)$. Sedangkan kecukupan karbohidrat responden sudah tergolong baik karena sudah sesuai dengan AKG (52,05\%).
Tabel 2. Konsumsi Kelompok Bahan Pangan oleh Ibu Hamil di Kecamatan Pedurungan Kota Semarang

\begin{tabular}{lll}
\hline Jenis Bahan Pangan*) & Mean \pm SD & Median (Range) \\
\hline Makanan Pokok & $5,91 \pm 1,92$ & $5,54(2,70-11,66)$ \\
Daging merah & $0,25 \pm 0,52$ & $0,00(0,00-3,51)$ \\
Daging unggas & $1,09 \pm 0,86$ & $0,84(0,00-3,67)$ \\
Ikan & $0,77 \pm 0,75$ & $0,62(0,00-2,92)$ \\
Telur & $0,68 \pm 0,52$ & $0,59(0,00-1,64)$ \\
Susu & $0,29 \pm 0,55$ & $0,00(0,00-2,50)$ \\
Kacang-kacangan & $1,89 \pm 1,33$ & $1,74(0,00-7,00)$ \\
Sayur & $1,56 \pm 0,78$ & $1,52(, 00-3,90)$ \\
Buah & $1,89 \pm 1,46$ & $1,64(0,00-8,36)$ \\
\hline *) dalam satuan porsi & &
\end{tabular}

Tabel 3. Angka Kecukupan Energi (AKE) dan Makronutrien Ibu Hamil di Kecamatan Pedurungan Berdasarkan kategori Penambahan Berat Badan

\begin{tabular}{|c|c|c|c|c|c|}
\hline \multirow{2}{*}{ Komponen Zat Gizi } & \multicolumn{3}{|c|}{$\begin{array}{l}\text { Kategori Penambahan } \\
\text { Berat Badan }\end{array}$} & \multirow{2}{*}{$\begin{array}{r}\text { Total } \\
(n=73)\end{array}$} & \multirow{2}{*}{$\%$} \\
\hline & $\begin{array}{r}\text { Kurang } \\
(n=21)\end{array}$ & $\begin{array}{r}\text { Normal } \\
(n=11)\end{array}$ & $\begin{array}{r}\text { Lebih } \\
(n=41)\end{array}$ & & \\
\hline \multicolumn{6}{|l|}{ Energi (\%AKG) } \\
\hline Sangat kurang $(<70)$ & 5 & 3 & 7 & 15 & 20,54 \\
\hline Kurang $(70-<100)$ & 14 & 6 & 20 & 40 & 54,79 \\
\hline Sesuai $(100-<130)$ & 2 & 2 & 13 & 17 & 23,28 \\
\hline Lebih $(\geq 130)$ & 0 & 0 & 1 & 1 & 1,36 \\
\hline \multicolumn{6}{|l|}{ Protein $(\% \bar{A} \mathbf{K P})$} \\
\hline Sangat kurang $(<80)$ & 9 & 2 & 9 & 20 & 27,39 \\
\hline Kurang $(80-<100)$ & 6 & 5 & 9 & 20 & 27,39 \\
\hline Sesuai $(100-<120)$ & 4 & 3 & 14 & 21 & 26,03 \\
\hline Lebih $>120$ & 2 & 1 & 9 & 12 & 19,17 \\
\hline \multicolumn{6}{|l|}{ Lemak (\%AKG) } \\
\hline Kurang $(\leq 100)$ & 13 & 9 & 24 & 46 & 63,01 \\
\hline Cukup $(>100)$ & 8 & 2 & 17 & 27 & 36,98 \\
\hline \multicolumn{6}{|l|}{ Karbohidrat (\% AKG) } \\
\hline Kurang $(<80)$ & 9 & 5 & 11 & 25 & 34,25 \\
\hline Sesuai (80-110) & 11 & 4 & 23 & 38 & 52,05 \\
\hline Lebih $(>110)$ & 1 & 2 & 7 & 10 & 13,69 \\
\hline
\end{tabular}

Tabel 4. Distribusi Frekuensi Penambahan Berat Badan Responden per Minggu

\begin{tabular}{lccrr}
\hline Karakteristik & N (73) & \% & Rerata \pm SD) $\left.^{*}\right)$ & Median $\left(\right.$ Rentang) $^{*}$ \\
\hline Penambahan berat badan $(\mathrm{kg})$ & & & & 0,49 \\
$-\quad$ Kurang & 21 & 28,8 & $0,49 \pm 0,20$ & $(0,09-0,96)$ \\
$-\quad$ Normal & 11 & 15,1 & \\
$-\quad$ Lebih & 41 & 56,2 & & \\
\hline Keterangan: ${ }^{*}$ dalam satuan kilogram $(\mathrm{kg})$ & &
\end{tabular}

Penambahan berat badan responden dalam penelitian ini diikuti dalam kurun waktu 8 minggu yang yang dimulai antara usia kehamilan 16-28 minggu. Kategori penambahan berat badan dihitung berdasarkan rekomendasi Institute of Medicine yaitu pada ibu hamil dengan kategori indeks masa tubuh normal sebesar 0,36-0,45 kg per minggu. ${ }^{2}$ Penambahan berat badan di bawah $0,36 \mathrm{~kg}$ termasuk kategori kurang dan lebih dari $0,45 \mathrm{~kg}$ dikategorikan lebih. Berdasarkan tabel 4 dapat dilihat bahwa sebaian besar penambahan berat badan responden $(56,2 \%)$ termasuk lebih.
Sebelum dilakukan analisis bivariabel sebelumnya dilakukan uji normalitas data untuk variabel total asupan energi, asupan karbohidrat, asupan lemak, dan asupan protein. Dari hasil analisis tersebut, didapatkan variabel karbohidrat tidak berdistribusi normal, sedangkan 3 variabel yang lain berdistribusi normal, sehingga pengkategorian pada variabel asupan karbohidrat menggunakan nilai median, sedangkan 3 variabel lainnya menggunakan nilai rerata. 
Tabel 5. Uji Bivariat Hubungan Total Asupan Energi dan Komponen Makronutrien dengan Penambahan Berat Badan Ibu Hamil di Kecamatan Pedurungan Kota Semarang

\begin{tabular}{|c|c|c|c|c|c|c|c|c|c|}
\hline \multirow[t]{3}{*}{ Variabel } & \multicolumn{6}{|c|}{ Penambahan Berat Badan Ibu Hamil } & & & \multirow[t]{3}{*}{ Nilai $p^{*)}$} \\
\hline & \multicolumn{2}{|c|}{ Kurang } & \multicolumn{2}{|c|}{ Normal } & \multicolumn{2}{|c|}{ Lebih } & \multicolumn{2}{|c|}{ Total } & \\
\hline & n & $\%$ & $\mathbf{n}$ & $\%$ & $\mathbf{n}$ & $\%$ & $\mathbf{n}$ & $\%$ & \\
\hline Total Asupan Energi & & & & & & & & & $\mathbf{0 , 0 1 3}$ \\
\hline - $\quad$ Rendah & 13 & 17,81 & 8 & 10,96 & 13 & 17,81 & 34 & 46,57 & \\
\hline - $\quad$ Tinggi & 8 & 10,96 & 3 & 4,11 & 28 & 38,36 & 39 & 53,42 & \\
\hline Asupan Karbohidrat & & & & & & & & & 0,174 \\
\hline - $\quad$ Rendah & 11 & 15,07 & 8 & 10,96 & 17 & 23,29 & 36 & 49,31 & \\
\hline - $\quad$ Tinggi & 10 & 13,70 & 3 & 4,11 & 24 & 32,88 & 37 & 50,68 & \\
\hline Asupan Lemak & & & & & & & & & 0,097 \\
\hline - $\quad$ Rendah & 12 & 16,44 & 8 & 10,96 & 16 & 21,92 & 36 & 49,31 & \\
\hline - $\quad$ Tinggi & 9 & 12,33 & 3 & 4,11 & 25 & 34,25 & 37 & 50,68 & \\
\hline Asupan Protein & & & & & & & & & 0,089 \\
\hline - Rendah & 13 & 17,81 & 7 & 9,59 & 15 & 20,55 & 35 & 47,94 & \\
\hline - $\quad$ Tinggi & 8 & 10,96 & 4 & 5,48 & 26 & 35,62 & 38 & 52,05 & \\
\hline
\end{tabular}

*) berdasarkan uji Chi Square

Nilai rerata dan median tiap-tiap variabel yang menjadi nilai cut off sebagai berikut: rerata total asupan energi responden yaitu 2194,04 $\pm 501,94$ kalori, rerata asupan protein sebesar 78,28 $\pm 21,69$ gram, dan rerata asupan lemak sebesar 72,22 $\pm 20,37$ gram. Sementara itu median asupan karbohidrat terdapat pada nilai 309,90 gram dengan rentang 131,95 - 607,45 gram.

Berdasarkan analisis statistik yang terdapat pada tabel 5, diperoleh bahwa variabel total asupan energi berhubungan dengan penambahan berat badan ibu hamil dengan nilai $\mathrm{p}=0,013$. Sedangkan asupan karbohidrat, lemak dan protein tidak berhubungan dengan penambahan berat badan ibu hamil $(p=0,174$; $p=0,097 ; p=0,089$ ).

\section{PEMBAHASAN}

Menurut Pedoman Gizi Seimbang, anjuran konsumsi makanan pokok dalam sehari sebanyak 3-4 porsi, lauk pauk 2-3 porsi, sayur 3-4 porsi, buah 2-3 porsi. ${ }^{25}$ Bila dibandingkan dengan hasil penelitian ini untuk makanan pokok dan lauk pauk rerata konsumsinya sudah melebihi dari anjuran PGS $(5,88$ porsi dan 4,98 porsi), sedangkan untuk konsumsi sayur dan buah masih belum memenuhi anjuran PGS (1,58 porsi dan 1,90 porsi). Sayur dan buah mengandung berbagai jenis vitamin dan mineral serta serat yang sangat dibutuhkan ibu hamil. Kurangnya konsumsi sayur dan buah menunjukkan kurangnya pemenuhan kebutuhan vitamin dan mineral oleh ibu hamil. Untuk itu ibu hamil membutuhkan suplementasi seperti tablet $\mathrm{Fe}$ dan asam folat sesuai dengan program pemerintah. Sayangnya, hanya $60,27 \%$ responden yang mengonsumsi suplemen tersebut (tidak ditampilkan dalam hasil penelitian).

Konsumsi daging merah masih sangat rendah yaitu rerata 0,25 porsi atau setara dengan 8,75 gram daging merah/ hari. Namun, jumlah ini jauh lebih tinggi dibandingkan dengan konsumsi daging merah (sapi dan kerbau) perkapita seminggu di Indonesia menurut laporan BPS tahun 2018 yaitu $0,009 \mathrm{~kg}$ perkapita perminggu, ${ }^{26}$ walaupun hanya $39,8 \%$ ibu hamil yang mengonsumsi daging merah.

Daging unggas dan ikan lebih banyak dikonsumsi oleh ibu hamil sebagai sumber protein hewani dibanding dengan daging merah. Daging unggas dan ikan lebih menguntungkan untuk dikonsumsi dari sisi ekonomis karena harganya yang lebih murah, maupun dari sisi gizi karena mampu memenuhi kebutuhan protein hewani dan lebih rendah lemak. Namun daging unggas dan ikan lebih rendah dalam kandungan zat besi dibanding daging merah. Zat besi sangat dibutuhkan oleh ibu hamil untuk mencegah terjadinya anemia desiensi besi yang dapat meningkatkan risiko bagi ibu hamil. ${ }^{27}$

Telur juga banyak dikonsumsi untuk memenuhi kebutuhan protein karena harga yang terjangkau. Rerata konsumsi telur oleh responden 0,70 porsi/ hari. Jenis telur yang dikonsumsi yaitu telur ayam negeri, telur bebek, dan telur puyuh. Tingkat konsumsi daging dan telur ayam di Indonesia masing tergolong rendah dibanding negara lain. Menurut perhitungan BPS, Kemenko Perekonomian, dan Kementan ditetapkan bahwa tingkat konsumsi penduduk Indonesia terhadap daging ayam hanya sekitar $11,5 \mathrm{~kg} / \mathrm{kapita} / \mathrm{tahun}$ dan telur hanya sekitar $6,63 \mathrm{~kg} / \mathrm{kapita} / \mathrm{tahun}$. Artinya, konsumsi telur perkapita Indonesia setara dengan 0,31 butir telur. ${ }^{26}$

Sumber protein nabati dapat diperoleh dari kacang-kacangan. Jenis kacang-kacangan yang dikonsumsi oleh ibu hamil di Kecamatan Pedurungan Kota Semarang yaitu kacang kedelai dalam bentuk olahan tahu dan tempe, kacang kedelai goreng, kacang tanah yang diolah dalam bumbu pecel, dan kacang hijau. Rerata konsumsi kacang-kacangan sebesar 1,89 porsi/ hari. Pola diit dengan konsumsi kacang-kacangan 
yang tinggi merupakan salah satu ciri khas diit mediterania yang saat ini dianggap paling baik khususnya untuk ibu hamil. Kacang-kacangan mengandung protein yang tinggi dan kadar lemak yang rendah sehingga dapat mencegah kenaikan berat badan yang berlebihan pada ibu hamil. ${ }^{28}$

Konsumsi susu pada ibu hamil di Kecamatan Pedurungan Kota Semarang rerata 0,30 porsi/ hari atau setara dengan 66,67 ml susu. Jenis susu yang dikonsumsi yaitu susu sapi segar, susu sapi UHT, susu bubuk untuk ibu hamil, susu sapi UHT untuk ibu hamil, dan susu kental manis. Susu kental manis banyak dikonsumsi dalam campuran jus buah. Susu sapi segar sebenarnya tidak dianjurkan untuk dikonsumsi ibu hamil karena kekhawatiran masih adanya kandungan bakteri berbahaya dalam susu segar. Jenis susu yang direkomendasikan untuk ibu hamil adalah susu pasteurisasi maupun UHT yang memiliki kandungan lemak yang rendah (low fat) sehingga dapat membantu mencukupi kebutuhan kalsium ibu dan janin, namun tidak berisiko menyebabkan kenaikan berat badan yang berlebihan. ${ }^{29}$

Penambahan berat badan dalam kehamilan merupakan hal yang penting karena dapat berpengaruh pada proses kehamilan, persalinan, nifas, bahkan memiliki efek jangka panjang untuk ibu dan bayi. Rekomendasi penambahan berat badan ibu hamil di trimester 2 dan 3 per minggunya sebanyak $0,36-0,45 \mathrm{~kg}$ untuk ibu hamil dengan indeks masa tubuh sebelum hamil dalam kategori normal $\left(18,5-20 \mathrm{~kg} / \mathrm{m}^{2}\right){ }^{2}$ Dalam penelitian ini hanya $15,1 \%$ responden yang penambahan beratnya sesuai rekomendasi IoM. Sebagian besar responden $(56,2 \%)$ justru mengalami penambahan berat badan lebih dari rekomendasi dan 28,8\% responden kurang dari rekomendasi. Hasil penelitian ini sejalan dengan penelitian Emmaculate et al di Malawi yang mendapatkan hanya sebagian kecil ibu hamil yang mencapai penambahan berat badan sesuai rekomendasi $(19,8 \%) .{ }^{30}$ Begitu pula dengan hasil penelitian Asefa di Etiophia yang menyatakan hanya 28\% ibu hamil yang penambahan berat badannya adekuat dan dari kategori ibu hamil dengan IMT sebelum hamil normal hanya $24 \%$ yang mengalami penambahan berat badan adekuat. Selain itu ibu hamil dengan IMT sebelum hamil normal memiliki rerata penambahan berat badan hamil yang tertinggi dibanding kelompok lainnya. ${ }^{31}$

Berdasarkan hasil penelitian, hanya $23,28 \%$ ibu hamil yang tercukupi kebutuhan energinya, sementara $74,33 \%$ ibu hamil belum tercukupi asupan energinya. Menurut tabel AKG Indonesia, kebutuhan energi ibu hamil trimester 2 dan 3 yaitu sebesar 2450 kalori untuk usia 30-39 tahun dan 2550 kalori untuk usia 20-29 tahun. ${ }^{24}$

Asupan energi berasal dari komponen karbohidrat, protein, dan lemak. Rerata ibu hamil mengonsumsi 311,25 gr karbohidrat per hari, asupan protein 71,96 gr per hari, dan lemak 78,28 gr per hari. $52,05 \%$ ibu hamil telah mencukupi kebutuhan karbohidratnya (80-110 \%AKG), sedangkan untuk lemak sebagian besar ibu hamil mengonsumsi lemak $<100 \%$ AKG yaitu sebanyak 63,01\% responden. Hanya $26,03 \%$ ibu hamil mengonsumsi protein dalam jumlah cukup (100-120\%AKG), bahkan 27,4\% ibu kecukupan proteinnya sangat kurang $(<80 \% \mathrm{AKG})$. Apabila asupan makronutrien dihitung berdasarkan persentasenya terhadap asupan energi, didapatkan asupan karbohidrat sebesar $56 \%$, lemak sebesar $31 \%$, dan protein sebesar $13 \%$. Ratio tersebut menunjukkan prosentase asupan lemak melebihi rekomendasi untuk wanita usia reproduktif, yaitu 30\%. Asupan karbohidrat dan protein sudah sesuai dengan ratio yang direkomendasikan, yaitu karbohidrat $50-60 \%$ dan protein minimal $12 \%$ serta tidak lebih dari $25 \% .^{32}$

Dari keempat variabel independen yang peneliti ajukan, tiga diantaranya menunjukkan hasil yang kontradiktif dengan hipotesis yang diajukan. Tidak terdapat hubungan antara asupan karbohidrat, protein, dan lemak dengan penambahan berat badan ibu hamil. Hanya total asupan energi yang didapatkan berhubungan dengan penambahan berat badan ibu hamil (nilai $p=0,031$ ). Terdapat kecenderungan ibu hamil yang asupan energinya tinggi mengalami penambahan berat badan yang lebih tinggi pula. Hal tersebut dapat dilihat dari ibu hamil dengan penambahan berat badan lebih yang asupan energinya tinggi menempati proporsi yang paling besar yaitu $38,36 \%$ dari total responden.

Hasil penelitian ini mendukung penelitian sebelumnya oleh Diemert et al yang menyatakan bahwa pada usia kehamilan 22 hingga 36 minggu ibu hamil dengan penambahan berat badan berlebihan memiliki rerata asupan energi yang lebih besar dibanding ibu hamil dengan penambahan berat badan kurang dan ideal. ${ }^{33}$ Penelitian Diemert et al juga menyatakan terdapat hubungan antara asupan energi dengan penambahan berat badan ibu hamil. Namun, dalam penelitian tersebut juga didapatkan hubungan antara asupan karbohidrat dengan penambahan berat badan ibu hamil yang mana peningkatan konsumsi 1 gr karbohidrat berhubungan dengan $17 \mathrm{~g}$ peningkatan berat badan hamil. ${ }^{34}$ Penelitian sebelumnya oleh Pathiratna et al, juga mendapatkan hasil adanya total penambahan berat hamil yang lebih rendah pada ibu hamil dengan komsumsi karbohidrat yang rendah. ${ }^{35}$ Sementara itu hasil penelitian lain oleh Ebrahimi et al sejalan dengan penelitian ini yang juga mendapatkan hasil tidak ada hubungan antara asupan lemak, protein, dan karbohidrat dengan penambahan berat badan ibu hamil. ${ }^{36}$ Di sisi lain, penelitian Carbal et al pada $297 \mathrm{ibu}$ postpartum di Brazil justru menunjukkan hasil adanya hubungan negatif antara asupan protein dengan 
penambahan berat badan hamil yang mana semakin tinggi asupan protein per $\mathrm{kg}$ berat badan ibu hamil berhubungan dengan semakin rendahnya kenaikan berat badan ibu. ${ }^{37}$

Pada penelitian ini, $71 \%$ responden tidak dapat mencukupi kebutuhan energinya, padahal 56,20\% responden mengalami kenaikan berat badan dalam kategori lebih dan 33,7\% dalam kategori normal. Hal ini menunjukkan kemungkinan adanya efisiensi metabolisme pada ibu hamil. Menurut penelitian Abeysekera, et al, ibu hamil sehat mengalami peningkatan masa lemak selama kehamilan walaupun dengan sedikit peningkatan total energy expenditure (TEE) dan tidak ada perubahan dalam asupan energi. Hal ini menunjukkan bahwa efisiensi penyimpanan energi meningkat selama kehamilan, yang mungkin terkait dengan perubahan mikrobiota usus dan aktivasi jalur anabolik selama kehamilan. Penjelasan mengenai faktor-faktor yang berperan dalam penyimpanan energi dan lemak yang efisien selama kehamilan ini, serta peran perubahan mikrobiota usus selama kehamilan, mungkin penting untuk mengendalikan kenaikan berat badan kehamilan. ${ }^{38}$

Pada trimester kedua dan ketiga kehamilan terjadi perubahan mikrobiota dalam sistem pencernaan yaitu adanya peningkatan Actinobacteria dan Proteobacteria, dan penurunan Faecalibacterium. Penelitian dengan mentransfer microbiota pada trimester ketiga pada tikus bebas kuman didapatkan adanya perubahan fisiologi setelah transfer microbiota tersebut, yaitu adanya penambahan berat badan dan resistensi insulin yang signifikan. Penemuan tersebut menunjukkan komponen mikroba secara aktif dapat berpengaruh pada imunologi dan metabolisme. Pada ibu hamil trimester ketiga, perubahan mikrobiota ini justru memberikan efek yang baik bagi kehamilan terutama untuk menyuplai kebutuhan perkembangan janin. ${ }^{39}$

Menurut Bell hasil penelitian yang tidak konsisten antara asupan energi dan makronutrien dengan penambahan berat badan menunjukkan adanya kebutuhan untuk dilakukannya penelitian yang lebih teliti mengenai metabolisme energi selama kehamilan untuk menghasilkan petunjuk praktis bagi tenaga kesehatan dan ibu hamil tentang kontribusinya pada kesehatan ibu dan penambahan berat badan ibu hamil. ${ }^{40}$ Penambahan berat badan yang optimal akan menurunkan risiko berbagai komplikasi kehamilan, persalinan, mencegah post partum weight retention, serta kesehatan ibu dan anak jangka panjang. ${ }^{41}$

Penelitian ini tidak terlepas dari keterbatasan. Pengkajian asupan makanan dengan food recall memungkinkan terjadinya pelaporan kuantitas diit yang kurang dari sesungguhnya (under reported) yang juga bisa dilakukan ibu hamil. Menurut penelitian Winkvist et al, underreported dalam wawancara food recall pada ibu hamil di Indonesia berkisar 14-46\%. ${ }^{42}$

\section{SIMPULAN}

Terdapat hubungan antara total asupan energi dengan GWG. Tidak terdapat hubungan antara asupan komponen makronutrien (karbohidrat, protein, dan lemak) dengan GWG. Sebagian besar ibu hamil mengalami EGWG. Konsumsi bahan pangan ibu hamil belum memenuhi pedoman gizi seimbang dengan kurangnya konsumsi sayur dan buah. Perlu diberikan pendidikan kesehatan pada ibu hamil mengenai kebutuhan nutrisi dalam kehamilan baik dari segi kuantitas maupun kualitas untuk mencapai penambahan berat badan hamil yang ideal.

\section{DAFTAR PUSTAKA}

1. Zeng Z, Liu F, Li S. Metabolic Adaptations in Pregnancy: A Review. Ann Nutr Metab. 2017;70(1):59-65.

2. Rasmussen KM, Yaktine AL. Weight gain during pregnancy: Reexamining the guidelines. Natl Acad Press. 2009;184(3):463-9.

3. American College of Obstetricians and Gynecologists. Weight Gain During Pregnancy. Committee Opinion No. 548. Obstet Gynecol. 2013;5(121):210-2.

4. Wen T, Lv Y. Inadequate gestational weight gain and adverse pregnancy outcomes among normal weight women in China. Int $\mathbf{J}$ Clin Exp Med. 2015;8(2):2881-6.

5. Soltani H, Lipoeto NI, Fair FJ, Kilner K, Yusrawati Y. Pre-pregnancy body mass index and gestational weight gain and their effects on pregnancy and birth outcomes: a cohort study in West Sumatra, Indonesia. BMC Womens Health. 2017;17(1):102.

6. Abubakari A, Jahn A. Maternal dietary patterns and practices and birth weight in Northern Ghana. PLoS One. 2016;11(9):1-17.

7. Fuller-Tyszkiewicz M, Skouteris H, Hill B, Teede $\mathrm{H}$, McPhie S. Classification tree analysis of postal questionnaire data to identify risk of excessive gestational weight gain. Midwifery. 2016;32:38 44.

8. Poston L, Caleyachetty R, Cnattingius S, Corvalán C, Uauy R, Herring S, et al. Preconceptional and maternal obesity: epidemiology and health consequences. Lancet Diabetes Endocrinol. 2016;4(12):1025-36.

9. Poston L. Obesity in pregnancy; Where are we, where should we go? Midwifery. 2017;49:4-6.

10. Hill B, McPhie S, Moran LJ, Harrison P, Huang TTK, Teede $\mathrm{H}$, et al. Lifestyle intervention to prevent obesity during pregnancy: Implications and recommendations for research and implementation. Midwifery. 2017;49(May 
2016):13-8.

11. Yang S, Zhou A, Xiong C, Yang R, Bassig BA, Hu $\mathrm{R}$, et al. Parental Body Mass Index, Gestational Weight Gain, and Risk of Macrosomia: A Population-Based Case-Control Study in China. Paediatr Perinat Epidemiol. 2015;29(5):462-71.

12. Huang A, Ji Z, Zhao W, Hu H, Yang Q, Chen D. Rate of gestational weight gain and preterm birth in relation to prepregnancy body mass indices and trimester: a follow-up study in China. Reprod Health. 2016;13(1):93.

13. Lee ACC, Katz J, Blencowe H, Cousens S, Kozuki $\mathrm{N}$, Vogel JP, et al. National and regional estimates of term and preterm babies born small for gestational age in 138 low-income and middleincome countries in 2010. Lancet Glob Heal. 2013;1(1):e26-36.

14. Kemenkes RI. Riset Kesehatan Dasar 2013. Kementrian Kesehatan Republik Indonesia. 2013. $1-303 \mathrm{p}$.

15. Murki S. Intrauterine Growth Retardation - A Review Article. J Neonatal Biol. 2014;03(03).

16. Johnson JL, Farr SL, Dietz PM, Sharma AJ, Barfield WD, Robbins CL. Trends in gestational weight gain: The Pregnancy Risk Assessment Monitoring System, 2000-2009. Am J Obstet Gynecol. 2015;212(6):806.e1-806.e8.

17. Harti LB, Kusumastuty I, Hariadi I. Hubungan status gizi dan pola makan terhadap penambahan berat badan ibu hamil. Indones $\mathbf{J}$ Hum Nutr. 2016;3(1):54-62.

18. Muktabhant $\mathrm{B}$, Lawrie TA, Lumbiganon $\mathrm{P}$, Laopaiboon M, Ta L, Lumbiganon P, et al. Diet or exercise, or both, for preventing excessive weight gain in pregnancy (Review). Cochrane Database Syst Rev. 2015;(6).

19. Tielemans MJ, Garcia AH, Santos AP, Bramer WM, Luksa N, Luvizotto MJ, et al. Macronutrient composition and gestational weight gain: A systematic review. Am J Clin Nutr. 2016;103(1):83-99.

20. Bärebring L, Brembeck $P$, Löf $M$, Brekke HK, Winkvist A, Augustin H. Food intake and gestational weight gain in Swedish women. Springerplus. 2016;5(1):377.

21. Fitriana N. Hubungan Asupan Energi, Protein, Karbohidrat, dan Lemak terhadap Peningkatan Berat Badan Ibu Hamil Trimester 1 dan Trimester 2 di Wilayah Kota Malang. Repository Universitas Brawijaya; 2017.

22. Yang L, Wu C, Bao Y, Zhou F, Lan X, Zhang Y, et al. Energy Intake as Determinants of Gestational Weight Gain in Chengdu. Wei Sheng Yan Jiu. 2018;47(6):895-905.

23. Badan Penelitian dan Pengembangan Kesehatan. Diet total study: Survey of individual food consumption Indonesia 2014. Ministry of Health Republic of Indonesia. 2014.

24. Kementerian Kesehatan Republik Indonesia. Peraturan Menteri Kesehatan Republik Indonesia Nomor 75 Tahun 2013 tentang angka kecukupan gizi yang dianjurkan bagi bangsa indonesia. Jakarta. 2013. p. 5-10.

25. Kementerian Kesehatan Republik Indonesia. Pedoman Gizi Seimbang. Kementerian Kesehatan Republik Indonesia; 2014.

26. Badan Pusat Statistik. Rata-Rata Konsumsi per Kapita Seminggu Beberapa Macam Bahan Makanan Penting, 2007-2018. Publikasi Statistik Indonesia. 2019. p. 1.

27. Mahan LK, Escott-stump S, Raymond JL. Krause's Food and the nutrition care process. 13th ed. St Lousis Missouri: Elsevier Saunders; 2012.

28. Silva-del Valle MA, Sánchez-Villegas A, SerraMajem L. Association between the adherence to the Mediterranean diet and overweight and obesity in pregnant women in Gran Canaria. Nutr Hosp. 2013;28(3):654-9.

29. The U.S. Food and Drug Administration Center. The Dangers of Raw Milk Protect Your Family with Wise Food Choices. 2006. p. 1-2.

30. Chithambo EST, Rhoda K, Holmboe-ottesen G. Factors associated with the rate of gestational weight gain in the rural Mangochi district of Malawi. University of Oslo; 2017.

31. Asefa F, Nemomsa D. Gestational weight gain and its associated factors in Harari Regional State: Institution based cross-sectional study, Eastern Ethiopia. Reprod Health. 2016;13(1):101.

32. Hanson MA, Bardsley A, De-Regil LM, Moore SE, Oken E, Poston L, et al. The International Federation of Gynecology and Obstetrics (FIGO ) Recommendations on Adolescent, Preconception , and Maternal Nutrition: " Think Nutrition First ." Int J Gynecol Obstet. 2015;4(131):213-53.

33. Gilmore LA, Burton JH, Butte NF, Ravussin E. Energy Intake and Energy Expenditure for Determining Excess Weight Gain in Pregnant Women. Obs Gynecol. 2016;127(5):884-92.

34. Diemert A, Lezius S, Pagenkemper M, Hansen G, Drozdowska A, Hecher $\mathrm{K}$, et al. Maternal nutrition, inadequate gestational weight gain and birth weight: results from a prospective birth cohort. BMC Pregnancy Childbirth. 2016;16(1):224.

35. Pathiratna ML, Sekijima K, Adakata M, Fujiwara $\mathrm{N}$, Muramatsu Y, Wimalasiri KMS. Impact of Second Trimester Maternal Dietary Intake on Gestational Weight Gain and Neonatal Birth Weight. Nutrients. 2017;9(627):1-12.

36. Ebrahimi F, Shariff ZM, Tabatabaei SZ, Fathollahi MS, Mun CY, Nazari M. Relationship between 
Sociodemographics, Dietary Intake, and Physical Activity with Gestational Weight Gain among Pregnant Women in Rafsanjan City, Iran. J Heal Popul NUtr. 2015;33(1):168-76.

37. Carbal M, Sichieri R, Rocha CMM da, Castro MBT de. Protein intake and weight gain among low-income pregnant women from Mesquita County, Rio de Jenaeiro, Brazil. Rev Nutr. 2018;31(3):275-86.

38. Abeysekera M V, Morris JA, Davis GK, Sullivan AJO. Alterations in energy homeostasis to favour adipose tissue gain: A longitudinal study in healthy pregnant women. Aust New Zael J Obstet Gynaecol. 2016;56:42-8.
39. Nuriel-ohayon M, Neuman H, Koren O. Microbial Changes during Pregnancy, Birth, and Infancy. Front Microbiol. 2016;7(July):1-13.

40. Bell R, Robson P. Lack of a signi fi cant relationship between energy intake in pregnancy and gestational weight gain underlines the need for further evaluations of energy metabolism during this time. Evid Based Med. 2016;21(5):2016-7.

41. American College of Obstetricians and Gynecologists. Weight gain during pregnancy. Committee Opinion. 2013. 1250-1253 p.

42. Winkvist A, Persson V, Hartini TNS. Underreporting of energy intake is less common among pregnant women in Indonesia. Public Heal Nutr. 2017;5(4):523-9. 